\title{
セメントペーストの自己収縮に及ぼす水セメント比の影響 \\ THE EFFECT OF WATER TO CEMENT RATIO ON THE AUTOGENOUS SHRINKAGE OF CEMENT PASTE
}

\author{
堀田智明*, 名和豊 春** \\ Tomoaki HORITA and Toyoharu NAWA
}

\begin{abstract}
In this study, we measured combined water of hydration, relative humidity and autogenous shrinkage of cement pastes which were made from various water-cement ratio in order to make it clear the mechanism of autogenous shrinkage of cementitious materials.

Relative humidity in hardened cement paste might be determined by the water-void ratio despite of water-cement ratio, and was linearly related with the autogenous shrinkage for the age after about 1 day. This correlation can not be explained by the capirary pressure, but can be explained by change of chemical potential that can be represented as a logarithmic function of relative humidity.
\end{abstract}

Keywords : Autogenous shrinkage, Water to cement ratio, Relative humidity, Chemical potential 自己収縮, 水セメント比, 相対湿度, 化学ポテンシャル

1. はじめに

最近, 高性能 $\mathrm{AE}$ 減水剂が開発され高流動・高強度コンクリート などの高性能コンクリートが一般建築物にも広く使用されている。 しかし，これらの高性能コンクリートでは, 水結合材比が小さく単 位結合材量が多いことから従来では大きな問題とならなかった自己 収縮が顕在化し，ひび割れが発生する危険性が指摘されている 1.2)。 これらの高性能コンクリートは，その使用用途から構造的に重要な 役割を果たしている部材である場合が多く，このような部位でひび 割れが発生した場合, 構造体に与える影響も相対的に大きいものと 考えられる。

コンクリートの収縮ひび割れに関しては, 古くから研究が行われ ておりる)，特に乾燥収縮に関しては多くの研究報告がなされている。 乾燥収縮の発生メカニズムに関しては, 毛細管張力理論, 表面吸着 理論, 層間水理論, 分離圧説 (浸透压説) 等多くの理論が提案され ている 1)，5)，6，7)。中でも，毛細管張力理論は比較的相対湿度が高い 領域の収宿機構として, 試験值と解析值が良く一致するとの報告例 もあり 8): !，自己収縮への適用性についての検討例も報告されてい る。一方で, Kelvin-Laplace 式から導かれる毛細管張力説の理論式 は, 分離圧説の式を表していることから, 計算される忘力は固体表 面を引張る力が働いているのではなく，化学ポテンシャルの異なる 水が接した場合に働くカであることも指摘されている ${ }^{10\}}$ 。こ観点
からは，収縮を生じる主要因は乾燥ではなく，硬化体中の吸着水の 化学ポテンシャルの低下と考えることができる。

このように，乾燥収縮および自己収縮の発生機構に関しては統一 された見解が得られておらず，自己収縮の有効な低减策が確立され ていないのが現状である。自己収縮の機構を解明寸るには，水和反， 応およびそれに伴う内部乾燥状態とあわせた考察が必要不可欠であ るが，セメント硬化体内部の乾燥状態を正確に把握できないこと， 硬化体の細孔構造が極めて複雑であるため, その応力がどの部位で 発生しているかを精度よく想定するのが困難であることがメカニズ ムの解明を困難にしている。

コンクリート内部の含水状態を非破壊で測定する方法に関して は古くから研究がなされてお゙り 111.12，最近，セラミックセンサー の電気抵抗を利用した内部相対湿度の測定法が提案されている 13)。 本研究では, 自己乾燥速度が異なるセメントペーストに関して, 水和反応, 内部乾燥および自己収縮の関係を調べ, 自己収縮の発生 機構について検討を加えた。すなわち，水セメント比を 4 水準設定 したセメントペーストを作製し，結合水率，相対湿度，自己収縮ひ ずみを測定し, 水和反応, 自己乾燥および自己収縮の関係について 検討した。また, 自己収縮の発生機構に関して従来から主要メカ二 ズムとして提案されている毛細管張力理論の適用性について検討す ると共に，化学ポテンシャルの観点からも整理を試みた。

\footnotetext{
* 北海道電力㑣土部 工修

** 北海道大学大学院工学研究科 助教授 $\cdot$ 工博
}

Hokkaido Electric Power Corporation Inc., Civil Engineering Dept., Architectural Engineering Section, M. Eng.

Assoc. Prof., Dept. of Structural and Geotechnical Engineering, Graduated School of Engineering, Hokkaido University, Dr. Eng. 


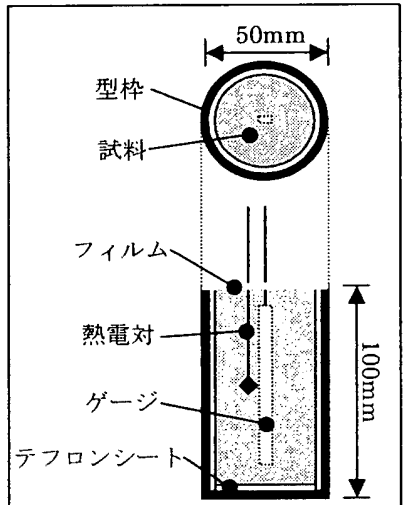

図 1 供試体概要

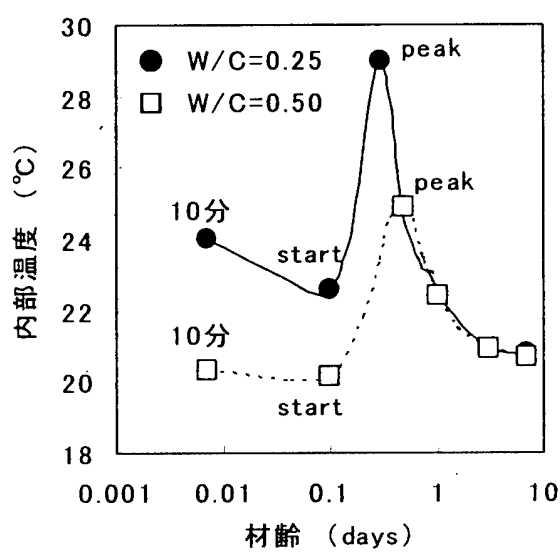

図 2 結合水率測定点

\section{2. 実験計画}

\section{1 使用材料および調合}

セメントには普通ポルトランドセメント（密度 $3.16 \mathrm{~g} / \mathrm{cm}^{3}$, 比表 面積 $3510 \mathrm{~cm}^{2} / \mathrm{g}$ ）を，混和剤にはポリカルボン酸系の高性能 AE 减 水剂を用いた。セメントペーストの調合は，水セメント比が 0.25 , 0.30，0.40 および 0.50 の 4 水準とした。なお，セメントペースト は材料を一括投入した後に，ハンドミキサーを用いて 3 分間練り混 ぜて作製した。

\section{2 試験項目および方法}

（1）自己収縮ひずみおよび供試体内部温度

自己収縮ひずみの測定は，既報で提案したように14市販のひずみ ゲージをシリコーンシーラントで被覆して作製した低弾性型 $\left(0.98 \mathrm{~N} / \mathrm{mm}^{2}\right)$ ひずみゲージを用いる方法により行なった。供試体 の概要を図 1 に示す。供試体は， $\phi 5 \times 10 \mathrm{~cm}$ の鋼製型枠で作製し， 型枠に試料を投入するのと同時にゲージを埋設した。なお, 試料が 長さ变化を起こす際, 型枠と試料との間に生じる摩擦を低减するた め, 型枠の内側にテフロンシートを敷いた。試料の打ち込み後は, 水分の逸散を防ぐため上部端面をビニルシートおよび伸縮性のフィ ルムで 2 重に封絾した。作製した供試体は室温 $20^{\circ} \mathrm{C}$, 相対湿度 $60 \%$ の恒温室で脱型せずに養生し，供試体作製直後から材齢 1 週間まで のひずみを測定し,同時に測定した 3 本の平均值を測定値とした。

（2）結合水率

内部乾燥と水和反応の関係について考察するため結合水率を測定 した。セメントペーストを所定の材齢に達した時点で粉砕し, これ

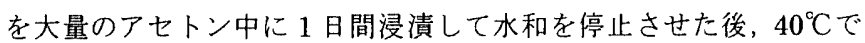
4 時間乾燥させたものを粉研し結合水量を求めた。結合水量は $1000^{\circ} \mathrm{C}$ での強熱減量から求め, 未水和のセメントの強熱減量を補正 して, 未水和のセメントに対する重量比率 (以後, 結合水率) で示 した。なお，結合水率の測定は図 2 に示すように，材龄 10 分，供 試体内部温度の上昇の開始点およびピーク，材齢 $1 ， 3 ， 7$ 日の計 6 点とした。また, 練り混ぜ時に投入した全水量から結合水量を差し 引いた未結合の水量をセメント重量で序した犆を自由水率とする。

(3) 相対湿度

相対湿度の測定は，湯浅らが提案する15.セラミックセンサーを用 いて行った。測定した電気抵抗は, 名和らが示した131電気抵抗と湿

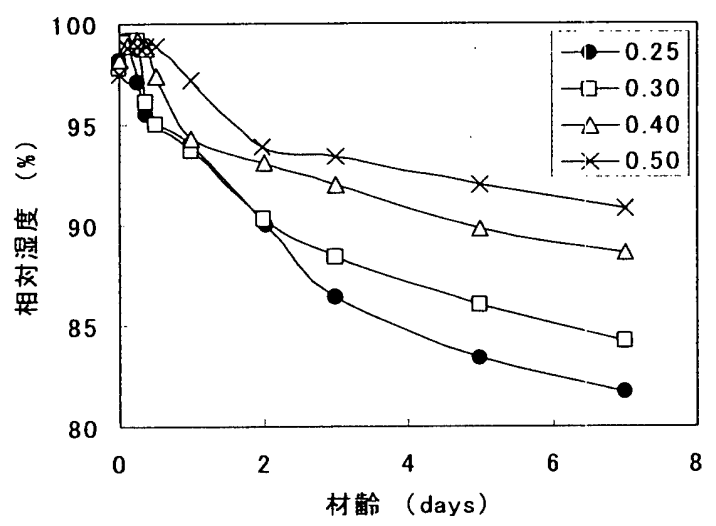

図 3 内部相対湿度の変化

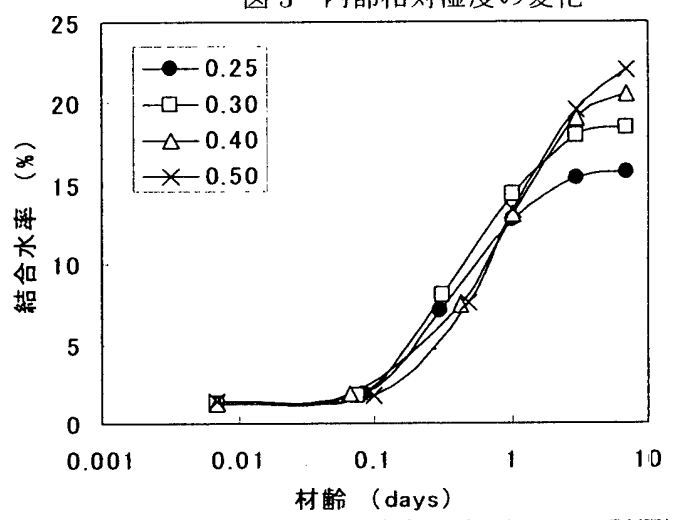

図 4 セメントペーストの結合水率（W/C の影響）

度の関係式により相対湿度に換算した。供試体は，ひずみの測定と 同様に $\phi 5 \times 10 \mathrm{~cm}$ の鋼製型枠で作製し，センサーは試料の中央に埋 設した。試料打ち込み後は水分の逸散を防ぐため上部端面を封縅し 供試体作製直後から材路 7 日までの相対湿度の変化を測定した。

\section{3. 実験結果および考察}

3.1 セメントペーストの自己収縮および内部相対湿度の変化

(1) 内部相対湿度の変化

図 3 にセメントペーストの内部相対湿度の測定結果を示す。図よ り，材齢の進行に伴い相対湿度は低下しており，7 日までの初期材 齢での低下速度は低水セメント比のものほど大きい。水セメント比 が 0.25 の供試体では材龄 7 日で相対湿度が約 $82 \%$ まで低下してい るのに対し，水セメント比 0.50 の供試体では約 $92 \%$ に留まってお り，水セメント比による内部の乾燥状態の差異を良く表している。

供試体が封絾状態である場合，硬化体内部の乾燥は水和反応に起 因する自己乾燥のみにより生じていると考えることができる。すな わち，相対湿度の低下は結合水率の増加に伴う自由水率の堿少によ り生じており，水セメント比による湿度低下の差異は自由水率の差 異に起因していると考えられる。図 4 にセメントペーストの結合水 率の変化に及ぼす水セメント比の影響を示す。図より，いずれの水 セメント比においても，供試体の内部温度の上昇開始点すなわち $\mathrm{C}_{3} \mathrm{~S}$ の水和開始を境に, 結合水率が増加しているのが分かる。また, 単位水量が少ない低水セメント比のペーストでは, 水和発熱により 供試体内部温度が高くなるため水和反応が若干促進されているもの の，材齢 1 日までの結合水率は，水セメント比に拘わらずほぼ同程 
度となっていることが分かる。しかし，材龄 1 日以降は，水セメン 卜比が小さいものほど結合水率の増加すなわち水和反応の進行が緩 慢になっている。このことは，未水和セメント付近の自由水が枯渴 してきたことを現しているものと考えられる。

図 5 に，結合水率と相対湿度の関倸を示寸。図上り，結合水率の 增加に伴い，相対湿度が低下していることが確認されるが，その関 係は水セメント比ごとに異なった曲線となっている。すなわち，同 じ結合水率では水セメント比が低いものほど相対湿度の低下が大き くなってている。これは，低水セメント比のものほど練り混ぜ時に投 入した最初の水量が少ないことから，結合水率が同程度であっても 自由水率が少ないためである。硬化体中の相対湿度の变化には，こ の自由水率が直接関与していると考えられるため，次に自由水率と 相対湿度の関倸を調べた。図 6 に, 自由水率と相詨湿度の関係を示 す。図より，自由水率の減少に伴い相対湿度が低下していることが 分かる。しかし，自由水率と相対湿度の関係も水セメント比ごとに 異なった曲線で表され，自由水率が等しい場合，高水セメント比の ものほど相対湿度が小さい結果となった。

セメント硬化体中では自由水（未結合水）は，気相と液相の成分 からなっているが，液相成分は水和物のゲル中に捕われている水， 固体表面への吸着水および毛細管水に分類される。これらの水分の 平衡状態は硬化体の細孔構造と密接に関連しているため, 細孔構造 もパラメタとして取り込まなければ相対湿度を表すことはできない と考えられる。本論文では，供試体中の自由水量と総空隙容量の比 として含水比 D を定義し，相詨湿度との関倸について検討した。こ れらの関係式を（1）式および（2）式に示す。

$$
\begin{aligned}
& D=\frac{W_{f}}{\phi_{t}} \\
& \phi_{t}=V_{W}+\phi_{H S}
\end{aligned}
$$

$$
\begin{aligned}
& \text { ここに, } \\
& D: \text { 含水比 }(\mathrm{kg} / \mathrm{l}) \\
& W_{f}: \text { 自由水量 }\left(\mathrm{kg} / \mathrm{m}^{3}\right) \\
& \phi_{t}: \text { 総空隙容量 }\left(1 / \mathrm{m}^{3}\right) \\
& V_{W}: \text { 自由水容積 } \cdot\left(1 / \mathrm{m}^{3}\right) \\
& \phi_{H S}: \text { 水和収縮量 }\left(1 / \mathrm{m}^{3}\right)
\end{aligned}
$$

総空隙容量は, 自由水の容積と水和収縮により生じた空隙の容積 の和として求めた。水和収縮量は，水和反応により消費されたすべ ての水が (3) 式に示すエーライトの水和反応によるものと仮定し， 結合水率の実測值を用いて算出した。なお，クリンカーおよび水和 物の密度は, Lea.F.M らの值 (6)を用いた。

$$
2 \mathrm{C}_{3} \mathrm{~S}+6 \mathrm{H}_{2} \mathrm{O} \rightarrow \mathrm{C}_{3} \mathrm{~S}_{2} \mathrm{H}_{3}+3 \mathrm{Ca}(\mathrm{OH})_{2}
$$

図 7 に, 求めた総空隙容量と結合水率の関係を示す。図より，水 七メント比が小さいほど総空隙容量は少ないことが分かる。

図 8 に含水比 $\mathrm{D}$ と相効湿度の関係を示寸。図より，含水比 $\mathrm{D}$ と 相対湿度の間には良好な相関関倸が認められ，含水比 D を用いるこ

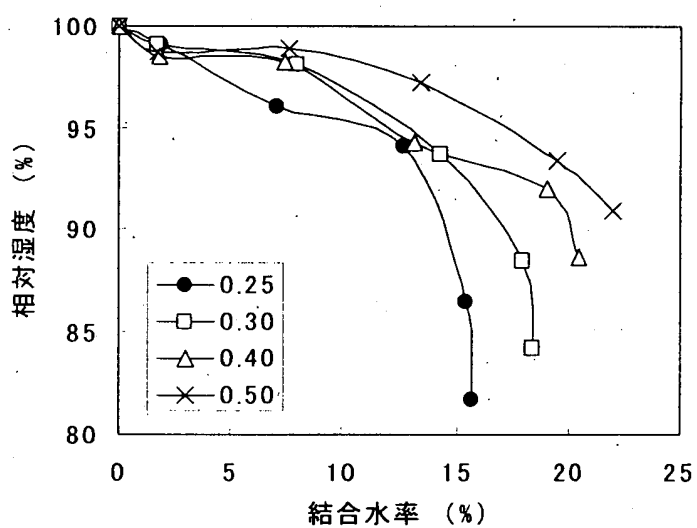

図 5 結合水率と相対湿度の関係

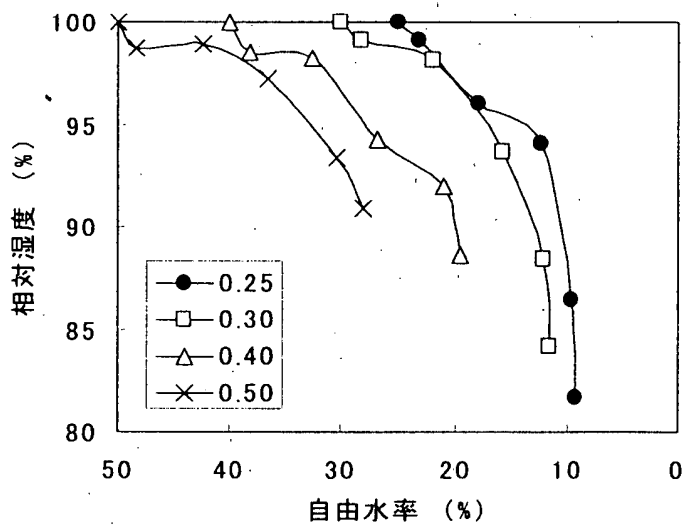

図 6 自由水率と相対湿度の関係

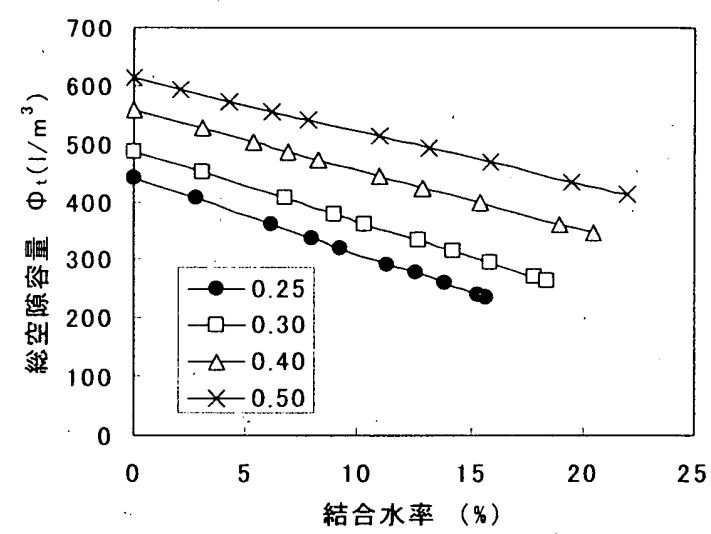

図 7 結合水率と総空隙容量の関倸

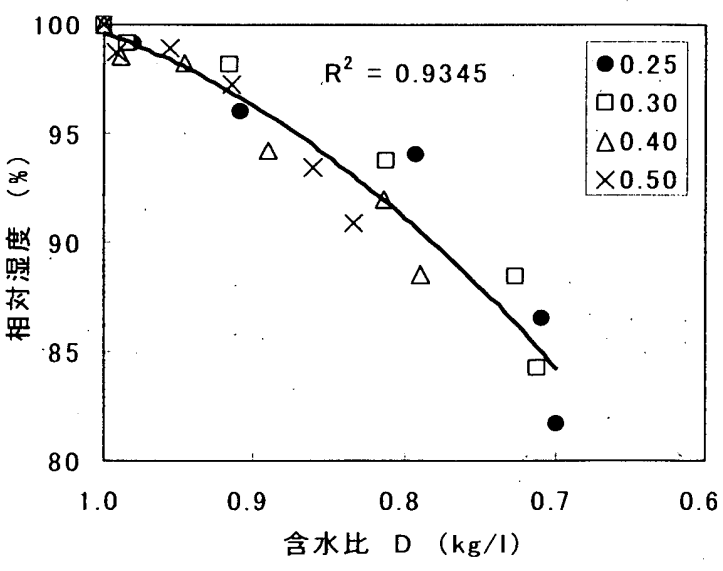

図 8 含水比と相対湿度の関係 
とにより水セメント比に拘わらず相対湿度を一義的に表現できるこ とが分かる。このことから, 本試験で得られた相対湿度の值は, 概 ね妥当であるものと判断され，さらに，細孔径分布を定義すること ができれば、相対湿度と液状水量の平衡状態を一一義的に定めること が可能と考えられる9。

（2）自己収縮ひずみと相対湿度

図 9 に, セメントペーストの自己収縮ひずみの測定結果を示す。 図より，自己収縮は材齢に伴って進展しておう，材龄 7 日の範囲で は水セメント比が低いものほど自己収縮ひずみが大きくなっている。 図 3 の相対湿度の変化と併せて考えると, 内部乾燥度合いの差がひ ずみに良く現れているのが分かる。また，水セメント比が低いもの は極初期材齢から急激に収縮が進展しているのに対し, 水セメント 比が高いものは膨張しているのが認められる。これらの自己収縮の 測定結果は，いずれも前報14とほぼ同じ結果である。

図 10 に相対湿度と自己收縮ひずみの関係を示寸。図より，相対 湿度と自己收縮ひずみの関係は水セメント比により異なった曲線を 示しており，水セメント比が低いほど同一の相対湿度に対して収縮 ひずみが大きくなっている。また、これらの水セメント比による差 異は，主に収縮が開始するまでの初期の举動の差によるものである ことが分かる。すなわち、低水セメント比の供試体では相対湿度の 低下に伴い単調にひずみが増大しているのに対し、高水セメント比 の供試体では極く初期の材龄で相対湿度が低下しているにも拘わら ず膨張が生じていることが確認される。しかし、一旦収縮が開始し た以降は相対湿度の低下に伴う自己収縮ひずみの増大の割合は水セ メント比によらずほほ同程度となっている。

\section{2 内部乾燥と自己収縮のメカニズム}

(1) 毛細管張力

従来から乾燥収縮のメカニズムとして毛細管張力説が提案されて いるが 1)，自己収縮のメカニズムとしてもこの毛細管張力説の適用 が考えられている2)。毛細管張力は，(4) 式，(5) 式に示す Laplace 式および Kelvin 式により与えられる。

$$
\begin{aligned}
& \Delta p=\frac{2 \gamma}{r} \\
& \ln \frac{P}{P_{0}}=-\frac{2 \gamma M}{R T \rho} \cdot \frac{1}{r}
\end{aligned}
$$

ここに,

$$
\begin{aligned}
& \Delta \mathrm{p}: \text { 毛細管張力 }\left(\mathrm{N} / \mathrm{mm}^{2}\right) \\
& \gamma: \text { 水の表面張力 }(\mathrm{dyn} / \mathrm{cm}) \\
& r: \text { 水面の曲率半径 }(\mathrm{cm}) \\
& P: \text { 蒸気圧 } \\
& P_{0}: \text { 飽和蒸気圧 } \\
& M: \text { 水の分子量 }(\mathrm{g} / \mathrm{mol}) \\
& R: \text { 気体定数 }(\mathrm{erg} / \mathrm{K} \cdot \mathrm{mol}) \\
& T: \text { 温度 }\left(^{\circ} \mathrm{K}\right) \\
& \rho: \text { 水の密度 }\left(\mathrm{g} / \mathrm{cm}^{3}\right)
\end{aligned}
$$

また（4）式および（5）式より，（6）式を得る。

$$
\Delta p=-\frac{R T \rho}{M} \ln \frac{P}{P_{0}}
$$

（6）式より，毛細管張力は相対湿度が与えられれば，細孔の半 径とは無関係に定まることが分かる。図 11 に，相対湿度の測定結 果から（6）式より算定した毛細管張力の経時変化を示す。図より， 毛細管張力は材齢に伴い大きくなっており，水セメント比が低いも のほど相対湿度の低下が大きいため，発生する毛細管張方も大きく なっていることが分かる。

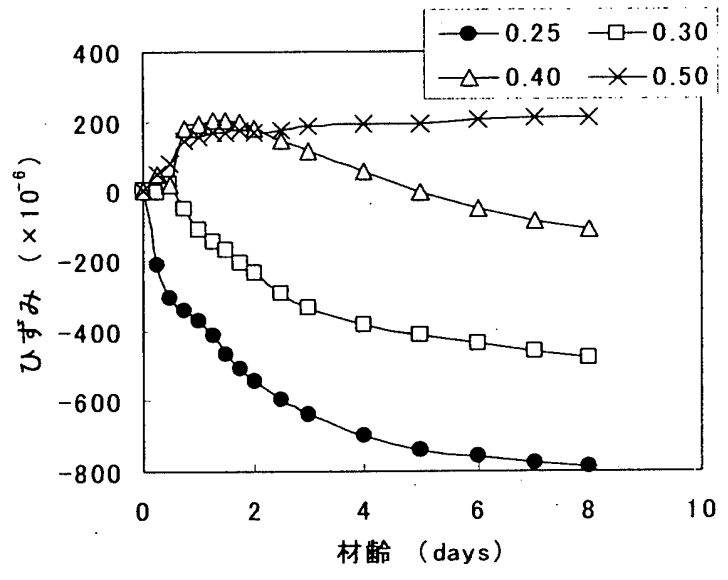

図 9 自己収縮ひずみの測定結果（W/C の影響）

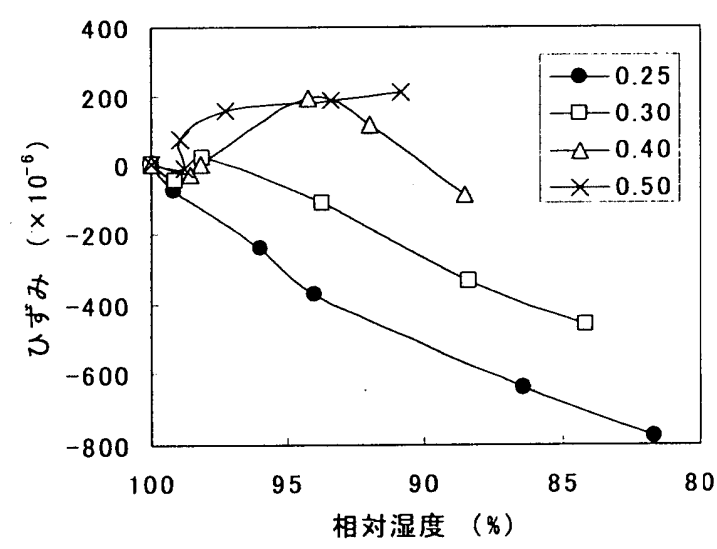

図 10 相対湿度と自己収縮ひずみの関係

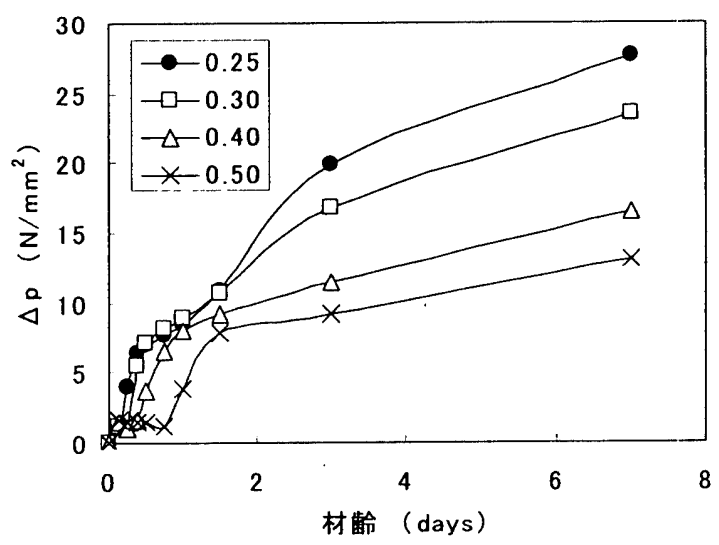

図 11 毛細管張力の推定值 
ここで，毛細管張力が硬化体中の液状水全体に均等に働いている と仮定した場合，毛細管張力による収縮応力および収縮ひずみはそ れぞれ（7）式および（8）式で示される。

$$
\begin{aligned}
& \sigma_{s h}=\Delta p \cdot \frac{e}{V} \\
& \varepsilon_{s h}=\frac{\sigma_{s h}}{E}
\end{aligned}
$$

ここに,

$\sigma_{\mathrm{sh}}$ ：毛細管張力による応力 $\left(\mathrm{N} / \mathrm{mm}^{2}\right)$

$\mathrm{e}:$ 液状水の体積 $\left(\mathrm{m}^{3} / \mathrm{m}^{3}\right)$

$\mathrm{V}:$ 硬化体の体積 $\left(\mathrm{m}^{3}\right)$

$\mathrm{E}:$ 硬化体のヤング係数 $\left(\mathrm{N} / \mathrm{mm}^{2}\right)$

$\varepsilon$ sh : 毛細管張力による自己収縮ひずみ

次に，供試体の変形が瞬間的な変形と時間依存性の変形寸なわち クリープひずみから成ると仮定し，重ね合わせの原理に基づく step-by-step 法によりクリープを考虑した収縮ひずみを求めた。ク リープ倸数は, 清原らが実験的に求めたセメントペーストのスペシ フィッククリープひずみの回帰式 17)、18) および（7）式の毛細管張 力による応力を基に算定した。図 12 に算定したクリープ係数の一 例を示す。セメントペーストのヤング倸数は石田ら (9)の提案した強 度発現モデルと建築学会の強度とヤング俰数の関倸式より計算した ものを用いた。図 13 にヤング係数の推定値を示す。また，図 14 に 石田らの推定值と，川上らが実測值より求めたセメントペーストの ヤング係数の回帰式 20)による推定値との比較を示す。図より，両推 定值の間に多少の差はあるものの，概齐一致した値を示しているこ とから、これらの推定値は妥当な值と考えられる。（7）式における 液状水の体積に関しては, 硬化体中の自由水の内, 水蒸気として存 在する量は微少であることから，結合水率の実測值より算定した自 由水を用いた。

毛細管張力理論による自己収縮ひずみの推定值を図 15 および図 16 に示す。なお，図 15 はクリープを考慮しない収縮ひずみの推定 值を，図16 はクリープを考虑した収縮ひずみの推定值をそれぞれ， 示す。図 15 より（8）式により推定した自己収縮ひずみの值は,

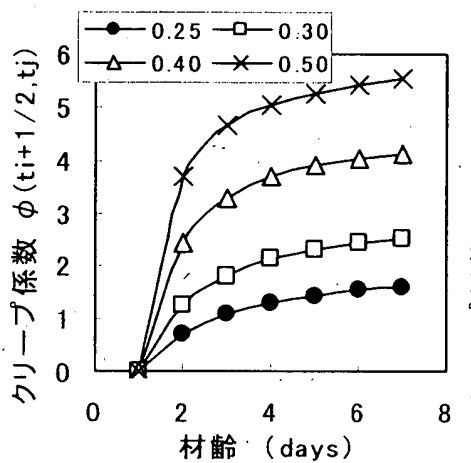

（a）載荷材齢 1 日

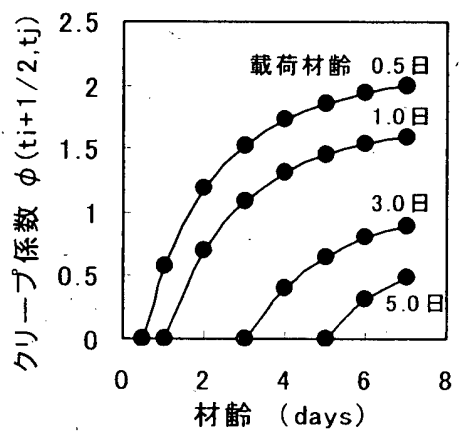

(b) $\mathrm{W} / \mathrm{C}=0.25$
図 12 クリープ係数の推定值

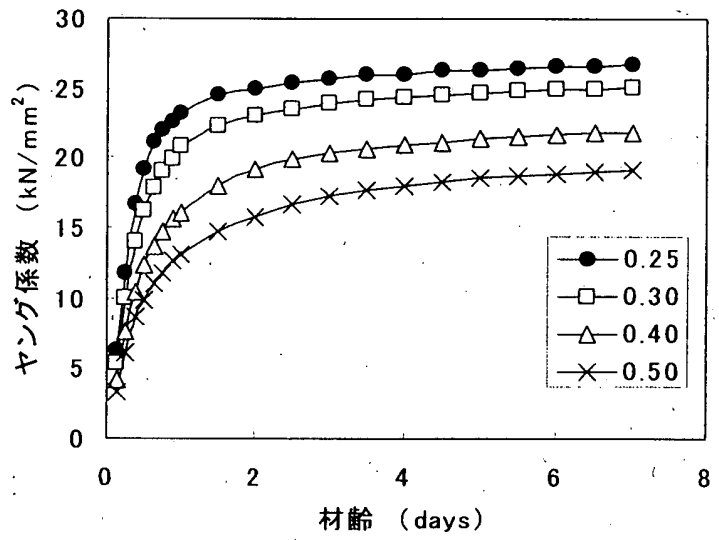

図 13 ヤング係数の推定値

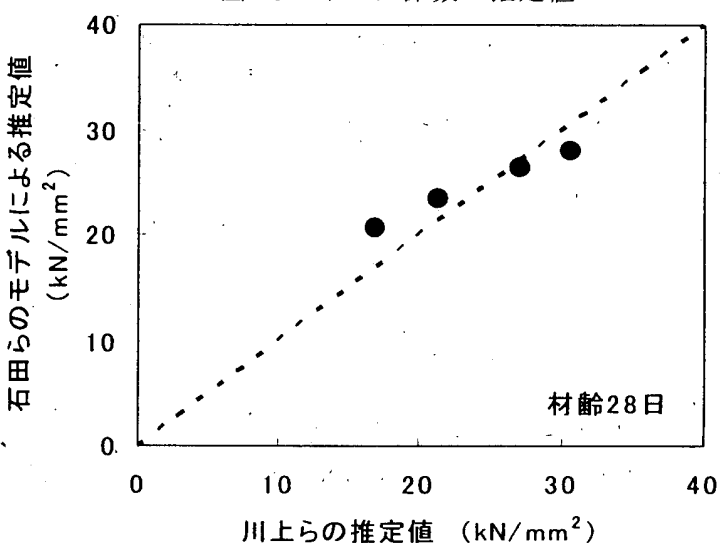

図 14 ヤング係数の推定值の比較

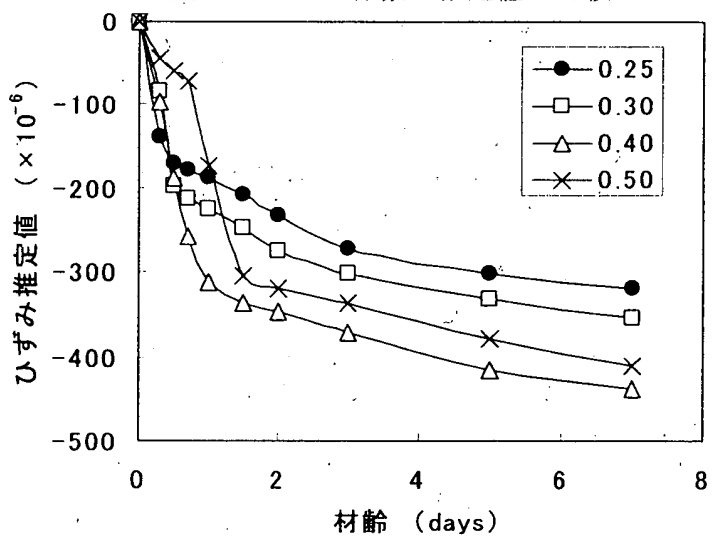

図 15 自己収縮ひずみの推定値（クリープを考慮せず）

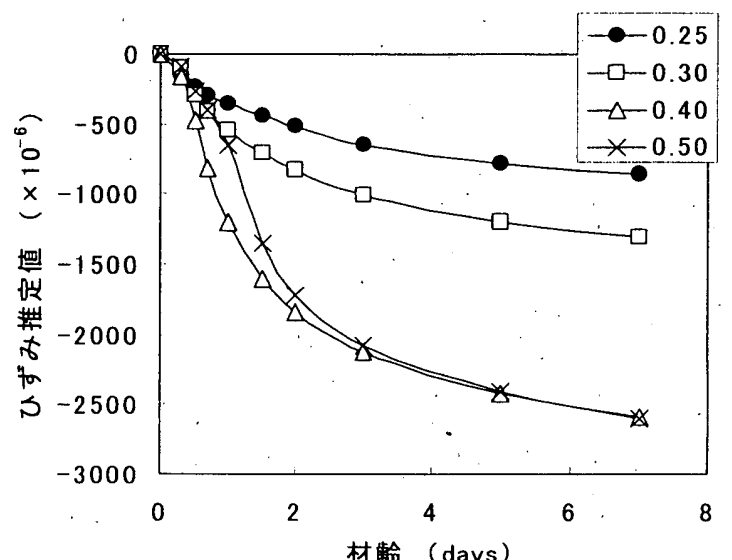

図 16 自己収縮ひずみの推定值（クリープを考虑） 
図 9 に示した実測値とは異なった傾向を示した。すなわち，奏測値 では水セメント比が低いものほど大きな収縮量を示したが，図 15 の推定値では高水セメント比のものほど大きな収縮量を示している。 さらに,クリープを考虑した図 16 の推定值では高水セメント比の セメントペーストにおいて収縮ひずみの増進が顕著になっており， 実測値とは大きく異なった傾向を示寸結果となった。図 11 に示し た毛細管張力の推定值では水セメント比が低いものほど大きな值を 示したが，低水セメント比のセメントペーストでは，高水セメント 比の供試体と比較して毛細管張力が働いている液状水の量が少なく, また，応力に対する変形抵抗も大きいため，毛細管張力による収縮 ひずみの大きさは必ずしも水セメント比の順にはならない。また， クリープ保数は高水セメント比のものほど大きな值を示すため, ク リープを考慮した場合, 高水セメント比のものほどひずみの增進が 顕著になるものと考えられる。したがって, 極初期材齡のクリープ 倸数の精度に若干の問題があったとしても，高水セメント比のもの ほどクリーブ係数は大きな値を示すことを考虑すれば，毛細管張力 理論による収縮ひずみの推定值は常に高水セメント比の供試体ほど 大きな值を示すことは明らかである。以上，毛細管張力理論による 自己収縮ひずみの推定值は実測値と大きく異なった傾向を示すこと から，自己収縮ひずみの挙動を毛細管張力理論のみで説明すること は困難であると考えられ，極初期材齢の挙動には膨張あるいは収縮 を生じさせる別のメカニズムが働いている可能性があるものと推論 される。

(2) 化学ポテンシャル

ここでは, 多田らが提案したように 10吸着水の化学ポテンシャル の低下によって収縮が発生すると考え, 収縮ひずみと化学ポテンシ ヤルの関係について考察する。硬化体中の自由水が熱力学的に平衡 な状態であれば, 各相の化学ポテンシャルは相等しい。すなわち, 硬化体の吸着水の化学ポテンシャルは気相水分の化学ポテンシャル と等しく, 次式で与えられる。

$$
\mu=R T \ln \frac{P}{P_{0}}
$$

$$
こ こ に,
$$

$$
\mu: \text { 吸着水の化学ポテンシャル }
$$

図 17 に，(9）式より求めた吸着水の化学ポテンシャルと収樎ひ ずみの関係を示す。図より，高水セメント比のものは初期に膨張举 動を示しており，低水セメント比のものは初期から収縮が生じてい るのが分かる。これらの極初期の举動については, 図 9 に示したひ ずみの経時変化でも触れたが, 化学ポテンシャルとの関保では, い ずれの水セメント比においても，一旦体積変化が休止し，その後収 縮が生じているのが分かる。化学ボテンシャルとひずみの関係では， 図 18 に示寸ように，極初期材齢の膨張や収縮が生じている領域 (stage I )，休止期（stage I）および休止期以降の収緶が進展する 領域（satege III）に分けて考えることができるが，それぞれの領域 で体積変化のメカニズムも異なることが予想される。休止期以降の
化学ポテンシャルの低下量 $(\Delta \mu)$ とひずみの增分量 $(\Delta \varepsilon)$ の関 係を図 19 に示す。なお，水セメント比 0.50 の供試体は材龄 7 日の 範囲では収縮举動を示さなかったため, 図 19 では除外した。図よ り，化学ポテンシャルの低下とひずみの進展の関係は水セメント比 に拘わらずほぼ同程度であることが分かる。このことは，休止期以 降の自己収縮ひずみの進展が吸着水の化学ポテンシャルにより一義 的に表現できる可能性を示しているものと考えられる。なお，(8) 式の， $\Delta p \cdot e / V$ を $\Delta \mu$ に置き換えることにより, 化学ポテンシャル の低下を駆動力と寸る硬化体の収縮ひずみを推定することができる。 一方, 水セメント比が低いほど変形に対する抵抗が大きいため, 同 じ応力に詨する硬化体の収縮量は低水セメント比のものほど小さく

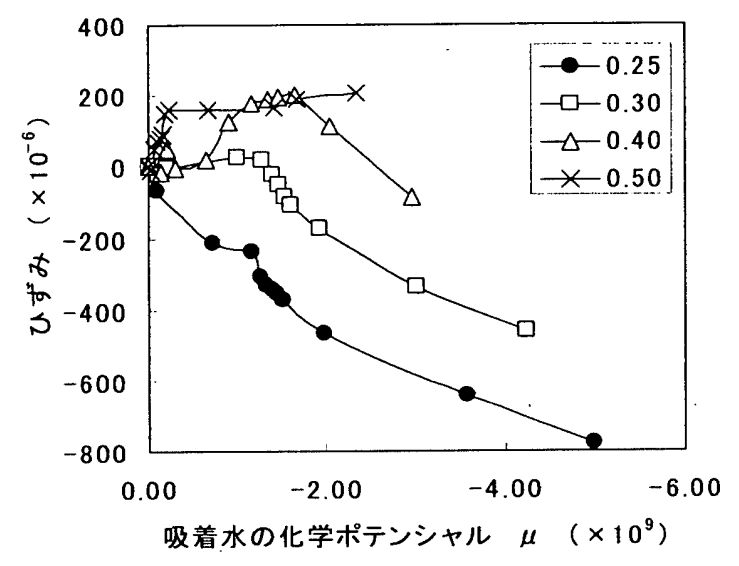

図 17 化学ポテンシャルと自己収縮ひずみの関係

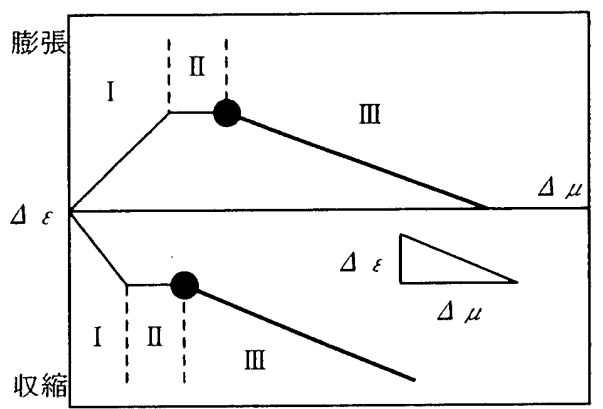

図 18 化学ポテンシャルとひずみの関係（概念図）

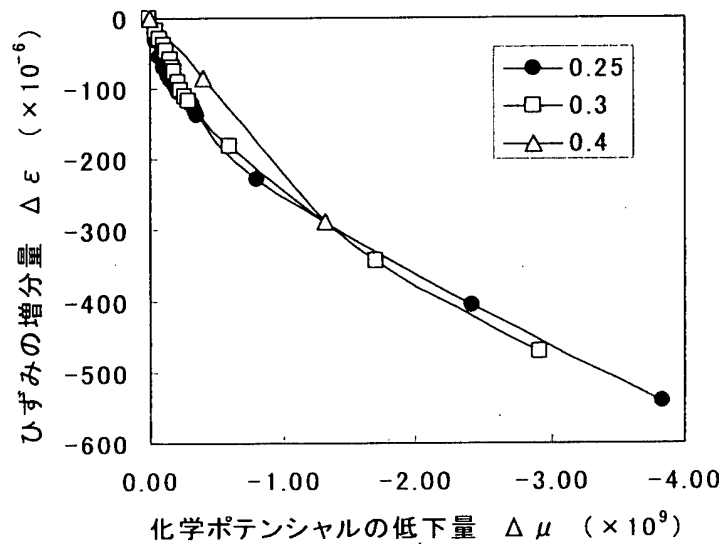

図 19 化学ポテンシャルと自己収縮ひずみの関係（stage III） 
なることが予想される。しかし，図．19 に示すように水セメント比 に拘わらず化学ポテンシャルの低下分に対してひずみの增進率は同 程度であった。このことは, 硬化体中の化学ポテンシャルが低下す ることにより，硬化体に外的な応力が働くのではなく，硬化体のゲ ル構造自身が収縮している可能性を示唆しているものと考えられた。

今後は，化学ポテンシャルと収縮ひずみの関係についてその適用 範囲を確認寸ると共に, 初期の膨張および収縮メカニズムについて 検討を加える必要があると考えられる。

\section{4.おわりに}

自己乾燥速度が異なるよう, 水セメント比を 4 水淮設定したセメ ントペーストに関して，結合水率，相対湿度および収縮ひずみをそ れぞれ測定した。これらの值を基に,セメントペーストの水和反忘， 内部乾燥およびひずみのつながりを把握し; 自己収縮の発生機構に つい検討を加えた。本研究の範囲で得られた知見を以下に示寸。

（1）セメントペースト内部の相対湿度を測定した結果, 水セメント 比が低いものほど, 相対湿度の低下速度が速く, 材齢 7 日の值 も小さい結果となった。

（2）内部相対湿度は，セメントと未反応の自由水量と総空隙容量の 比である含水比 $\mathrm{D}$ を用いることにより，水セメント比に拘わら ず一義的に評価できる可能性が示された。

（3）自己収縮ひずみを測定した結果，低水セメント比のものほど収 縮ひずみが大きい值を示した。相対湿度とひずみの関係では， 極初期の材齢において，内部の乾燥が進行しているにも拘わら ず高水セメント比の供試体で膨張挙動が認められた。

(4) 相対湿度の実測値から毛細管張力理論により推定値した自己 収縮ひずみの值は実測值と異なった傾向を示した。すなわち， 実測值では水セメント比が小さいほど大きな収縮を示すが，毛 細管張力理論による推定值ざは, 水セメント比の大きなものほ ど大きな収縮が生じる傾向を示し，毛細管張力理論のみで自己 収縮挙動を説明するのは困難であると推論された。

（5）自己収縮ひずみとペース卜内部の相対湿度より求めた吸着水 の化学ポテンシャルの関倸について考察した結果, 化学ポテン シャルの低下に伴う膨張，収縮が生じる極初期材齢の領域と， 休止期を経た後の化学ポテンシャルの低下に伴い収縮のみが 生じる領域に分けられることが分かった。この内，後者におけ る化学ポテンシャルの低下量とひずみの増分量の関係は，水セ メント比の影響を受けないことから，硬化体の変形抵抗に依存 せずゲル構造自身が収縮している可能性も示唆された。

\section{参考文献}

1）田澤栄一, 宮澤信吾, 重川幸司：水和反応に上る勃果セメントペースト のマクロな体積堿少, セメント・コンクリート論文集, No.45, pp.122·127, 1991

2）田澤栄一，宮澤信吾：セメント系材料の自己収縮に及ほ寸結合材および 配合の影響，士木学会論文集，No.502/V-25，pp.43-52，1994.11

3) Wittmann, F. H. : The structure of hardened cement paste - A basis for a better understanding of the materials properties, Proc. Hydraulic cement pastes : their structure and properties, Univ. Sheffield, pp. 96-117, 1976.4
4) Powers, T. C., F. Wittmann, R. F. Feldman, P. J. Sereda, R.H. Mills, S. Coutinho : Session 6 Final Report and Conclusion, RILEM Materiaux et Constructions, Vol.2,'No.8, pp.153·162, 1969

5) Powers, T.C. : Mechanism of shrinkage and reversible creep of hardned cement paste, Proc. Int. Symp. Struct. Corcr., pp.319-344, London, 1965

6) Bazan, Z. P. : Surface-diffusion theory for drying creep effect in Portland cement paste and concrete, Journal of American Ceramic Society, 56(5), pp.235-241,1973

7) Derjaguin, B.V., Churaev, N.V., Polymolecular adsorption and capillary condensation in narrow slit pore, J. Colloid and Interface Science, 54, pp.157-175, 1976

8）長滝重義，米倉要州夫：コンクリートの乾燥収縮およびクリーブの機楎 に関する考察, コンクリート工学論文, Vol.20, No.12, pp85-95, 1982.12

9）下村匠，小澤一雅，前川宏一：細孔容積分布密度関数に基づくコンク.リ 一トの乾燥収縮モデル, コンクリートエ学年次論文報告集, Vol.15, No.1, pp.435·440, 1993

10）田代忠一他編：空隙中の水の性質，セメント・コンクリート中の水の举 動, TCR, pp.233-239, 1993

11）十代田三郎, 十代田三知男，田村恭：モルタル及びコンクリートの含水 率の電気的測定法, 日本建築学会関東支部研究発表会 (第 1 報, pp.33-36, 1955.2 ，第 2 報，pp.41-44，1955.9，第 3 報 pp.33·36，1956.2)

12）鎌田英治，田畑雅幸，中村陽一郎：コシクリート内部含水量の測定，七 メント技術年報 XXX，pp.288-292，1976

13）名和豊春，出雲健司，矢野めぐみ，湯浅昇。: モルタル硬化体中の湿度変 化と自己收縮の関係, セメント・コンクリート論文集, No.55, pp.218-225, 2001

14）煀田智明，名和豊春：セメント系材料の自己收縮に関する研究，日本建 築学会構造系論文集，第 542 号, pp.9·15, 2001.4

15）湯浅昇，笠井芳夫，松井勇：埋め込みセラミックセンサーの電気特性に コンクリートの含水率測定方法の提案, 日本建築学会構造系論文集, 第 498 号, pp.13-20, 1997.8

16) Lea.F.M and Desch.C.H. : The Chemistry of Cement and Concrete, Edward Arnold Ltd. (1956)

17）清原千鶴, 佐藤嘉昭, 永松静也：セメントペーストの圧縮クリープ特性 に関する研究，セメント・コンクリート論文集，No.51，pp.812-817， 1997

18）清原千鶴，佐藤嘉昭、長松静也：水和過程にあるセメント供試体延バー シッククリーブに関寸る研究，七メント・コンクリート論文集，No.52， pp.1036:1041, 1998

19）石田哲也，R.P.CHAUBE，岸利治，前川宏一：微視的機構に基づくコン クリートの自己収縮，乾燥収縮およびその複合に関する解析的研究，土 木学会論文集, 'No.578/V-37, pp.111-121（1997.11）

20）川上英男，松田勝彦，熊井雄大：セメン卜硬化体の弾性係数について， コンクリート工学年次論文報告集，Vol.16，No.1，pp.497·502，1994

謝辞 本研究を行うにあたり，北海道立北方建築総合研究所の桂修 氏，日本大学の湯浅昇氏および清水建設（株）の橋田浩氏に多大な ご協力を頂きました。ここに感謝の意を表します。

(2002年 6 月 7 日原稿受理, 2002 年 12 月 24 日採用決定 